\title{
Inter-group Relations in Africa: The Amurri-Ugbawka Groups, to 1983
}

\author{
Dan 0. Chukwu
}

Department of History and International Studies, Nnamdi Azikiwe University, Awka, Nigeria.

Email: danchukwu2005@yahoo.com

\section{Doi:10.5901/mjss.2014.v5n20p2039}

\section{Introduction}

The assertion that the several towns and villages in the Nkanu clan of the Igbo country are unrelated (Milgov 1936) to one another may after all not be true. A closer study of certain characteristics of the social organizations, legends of origin, economic and political institutions among the village groups and people tends to counter this assertion. In other words, some of the groups can hardly accept such a description, as very often they prefer to trace their origins to a common source. For instance, Agbani and Akpugo, are said to trace their origin to Ubuleke Ukulu (the founder of Akpugo). According to tradition, it was Ani Obodo, the son of Ubuleke, who founded Agbani. It is believed that at a time out of human memory, Ani Obodo wandered away from Obele Akpugo (the present Akpugo where Ukulu had lived) on a hunting expedition. While resting under an Agba tree, continued the source, it occurred to his (Ani Obodo's) subconscious that the land on which he was hunting was rich enough for human settlement. He thus settled there, and named it Agbani, after the Agba tree (Enechukwu1993:31; Eze, Mbah and Ezeah 1999:27). Until date, this myth of common origin is known to bind Agbani and Akpugo together. It is also said that in the past, both towns formed an alliance with Nike, Oruku and Ezza against the Awkunanaw confederation (Milgov 1936).

Similarly, Ugbawka, a town located in central southern Nkanu, is comprised of nine villages some of whose descendants are believed to have migrated from neighbouring towns, particularly Akpugo, Nara, Awkunanaw, Ihuokpara, Nkerefi, Nomeh, Akpawfu and Amurri (Milgov 1936.5). The present paper is, therefore, interested in an examination of the extent of the relations that have over time subsisted between Ugbawka and its immediate neighbours. It is particular about Ugbawka and Amurri village groups in Enugu State, Nigeria, as a case study. The paper is structured into a number of sections prominent among which are examinations of the legends of origins of the two towns, geography of the towns, religious and judicial relations.

\section{Geography of Ugbawka and Amurri}

As noted elsewhere in the study, Ugbawka is among the towns that nature has caused to be located in the central southern part of Nkanuland of Enugu State, Nigeria. It is bordered on the north by Agbani and Akpugo, and on the south by Nomeh, Nara and Mburubu. It is also bordered on the east by Ihuokpara, and on the west by Amurri, Ogbaku and Nenwe (the last two towns are in Awgu and Aninri Local Government Areas of Enugu State, respectively) (Milgov 1936:3). The population of Ugbawka, according to the Intelligence Report of 1936, was estimated at 8,900 persons. At the time, it had a density population of 274 persons per square mile (Milgov 1936). According to the 1953 census figure, the population of Ugbawka stood at 16,985, (Okoye 1996:179).

The town is said to cover about an area of a hundred and eight square kilometres or fifty-four square miles with an average density of three hundred persons per square kilometres (Milgov1936). Often the area is low-lying, well-watered, and to a large extent, fertile. Parts of Ugbawka, especially the southern parts, are swampy during the rainy season (Milgov 1936). In the recent times, much of the forests seem to be disappearing due to the influence of modernity. Shrubs and mangrove vegetations are known to cover the vast farmlands and the residential neighbourhoods (Mbah 1997:2).

The area lies at the base of the Udi escarpments (Milgov 1936:4). All the rivers normally rage their torrents during the rains, and traverse the area in a south- easterly direction (Mbah 1997:2). The rivers are the Asu, Ojorowo, Ovu and lyi-Akpu. One characteristic of these rivers is that none hardly proves impassable even during the heaviest rain-although there had been occasions in the past when they overflowed their banks only to disappear within hours. (Edemba 2009).

Of interest is the passage of the tracks of the Nigerian Railway Corporation (Eastern lines) from Port Harcourt to Enugu. The line bisects the town from the South to the North, and has a rail station located at the Obeagu village of the 
Amafor quarters of the town (Milgov 1936). The effects of the railway station at Obeagu were many and divergent. First, they provided a strong nucleus for further migration and settlement of human population along the rail line and its neighbourhood. The by-product of this was the provision of modern social and economic amenities such as schools and churches. Secondly, the railway station at Obeagu provided a ready entrepot from where goods that came in from Port Harcourt, Aba, Umuahia and Enugu (in Eastern Nigeria) and Kano, Jos and Kaduna (in Northern Nigeria) in the heyday of rail transportation were distributed to the hinterland. (Anyanwu 2007)

Basically, Ugbawka is divided into two quarters -Obinagu and Amafor- with a total of nine villages. The villages are Amauzam and Isigwe for the Obinagu quarters. For the Amafor quarters, the villages are Amagu, Amanakwechi, Amankwo, Ihuona ,Ishienu, Obeagu and Umuisu. It is said that what is at present described as a monolith Amafor quarters used to be comprised of two quarters- Imeama and Amafor quarters. At the time, says a source, Imeama consisted of Amankwo, Amanakwechi, Ihuona and Obeagu villages, believed to be maternally related (Mbah 1997). These two quarters, which were characteristically separated by the Ojorowo River, have since fused to produce a single Amafor quarters (Mbah 1997).

On the other hand, Amurri is located in the central southwestern Nkanu of Enugu State. According to the 1936 Intelligence Report on the Amurri-Ugbawka Group, the town's population was estimated at 5,900 persons (Milgov 1936). In 1963, the town's population figure stood at 8,990, whereas that of 1987 was 15,260 ; for 1989 , it was 17,084 , while that of 1990 showed 17,511 (Enechukwu 1993:13-20). Amurri is bounded on the north by Umueze and Obe, on the east by Ugbawka and Agbani; on the south by Ogbaku, and on the west by Agbogugu.

Also, like the Ugbawka terrain, the land area of Amurri is low lying, well -watered, and fertile. Parts of the town are said to be swampy during the rains (Milgov 1956). This, perhaps, accounts for rich agricultural yields in garri, yam, rice and other agricultural items. The community also produces large quantities of palm oil and kernel (Nweke 2009).

Like Ugbawka, Amurri is said to be located at the base of the escarpments of the Udi hills (Milgov 1956). Unlike Ugbawka, however, the town is not known to have been fortunate to have the rail track run through it. Besides, the only major road that runs through the town takes its root from Agbani and terminates at Ugbawka, where it links with the Nweke Amankwo Road. The effect of the untarred road on modern economy is that it hampers movement of goods and services from where they are produced to the centre where they are in high demand. This has been the burden of the Amurri economy over the years (Nweke 2009).

\title{
3. Myths of Origin
}

Amurri and Ugbawka, argued S.P.L. Beaumont, a British anthropologist and Assistant District Officer (ADO) for Nkanu Area in 1936, had little legends, tradition and early history (Milgov 1936; Milgov 1956). In another breath, Beaumont had argued that the people had affinities with other towns of the southern Nkanu Area, and that throughout this area customs and organisation are very similar (Milgov 1936:5). That was a European anthropologist trying to write the history of a preliterate African society. In most other instances, European historians and anthropologists in colonial Africa preferred to dismiss Africans as having no history. The case of Hugh Trevor-Roper, a Regius professor of modern history at Oxford University, London, may suffice here. Trevor-Roper had, in response to students' request for a course on African history, stunned his audience with a story of a barbarous African society. According to him:

\begin{abstract}
Undergraduates, seduced, as always, by the changing breath of journalistic fashion, demand that they should be taught the history of black Africa. Perhaps, in the future, there will be some African history to teach. But at present there is none, or very little: there is only the history of the Europeans in Africa. The rest is largely darkness, like the history of pre-European, pre-Columbian America. And darkness is not a subject for history... for certainly we cannot study it... indeed we may neglect our own history and amuse ourselves with the unrewarding gyrations of barbarous tribes in picturesque but irrelevant corners of the globe: tribes whose chief function in history, in my opinion, is to show to the present an image of the past from which, by history, it has escaped; or shall I seek to avoid the indignation of the medievalists by saying from which it has changed? (Trevor-Roper 1963).
\end{abstract}

In the nineteenth century, George W.F. Hegel, a German philosopher of history, had made a statement similar to that of Trevor-Roper. According to him, "Africa is no historical part of the world; it has no movement or development to exhibit" (Hegel 2001:116).

In our context, we are able to see Beaumont struggling to admit that even though the people had some legend, tradition and early history, it was all in a little measure and proportion, with probably a high preponderance of affinities throughout the length and breadth of Nkanuland (Milgov 1936:5). Such arrogant (and sometimes misleading) statements were often made and upheld by the Europeans during the colonial period probably because they felt that Africans were 
primitive, (Uya 2007:17) and to that extent needed some European paternalism. As a Eurocentric writer of the period would boastfully argue, "History begins when men take to writing" (Newton 1923:267). A.P. Newton, the proponent of the above thesis, undoubtedly would have concluded that Africa is no part of world's history, since its history is largely unwritten.

There are, however, variants regarding the origin of Ugbawka. These variants may not have been unrelated to the many villages that make up the town. According to Beaumont, it would appear that Ugbawka is "composed of the descendants of bands of settlers from other towns, particularly Akpugo" (Milgov 1936:5). Some of the people, he asserts, also claim relationship with eight other towns-Nkerefi, Lengwe (Nenwe), Awkunanaw, Amagunze, Akpawfu, Nomeh, Mburubu, and Obeagu village of Amurri (Milgov 1936:5-6). The people, he adds, also claim relationship with Odume Achala. However, the people of the Imeama quarters appear to have claimed some relationship with the Ezza, and consistently denied any relationship or friendship with Akpawfu and Nomeh (Milgov 1936:6). The extent of affirming this claim and at the same time refuting any relationship with the Ezza, the Akpawfu and Nomeh, on the other hand, may yet open another vista of historical discourse which is beyond the scope of the present study.

In Ugbawka, however, two traditions of origin appear to be prominent among the people. They are the legend surrounding Nvuode and Iwana. According to the Nvuode phenomenon, at a time out of human memory, the area was probably founded by Ezike Uba, the son of Nvuode of Achalla, a town very close to Awka in Anambra State. At the time when hunting and gathering constituted the hub of man's economic activities, it is believed that Ezike Uba probably left Achalla on a hunting expedition. When he arrived the area, he made spirit efforts to establish his authority and influence. According to our source,

\begin{abstract}
He met the people of Ukwoka [believed to be the original inhabitants of the area). He was chased out by the people (the Ukwoka but he went back to Achalla in Awka and came back to Ugbawka with a multitude of other hunters who helped him in chasing the Ukwokas out of the area, before he finally settled at Amadogbu in Uhuona (Mbah 1997).
\end{abstract}

At Amadogbu, Ezike Uba begot sons, including Aneke Uba, Igom Uba and Ogbu Uba. It has been stated that Aneke Uba left Amadogbu on a hunting expedition, and in the process, he settled at Obodo Ufu (Obodo Ukwu) in Ogonogo Ihuona, where he begot Aneketa, Chime Aneke, Njoku Aneke, and Ejim Aneke. On his part, Igom Uba was said to have migrated from Amadogu to found Amagu Ugbawka. Ogbu Uba, on his part, was believed to have also founded the Obeagu village (Enechukwu 1993:52-53).

In Amurri, there are also varied myths regarding the people's origin with virtually every group tracing its origin to either within or without the area. While, for instance, the people might have claimed no relationship with the neighbouring towns, except in so far as the Obeagu quarter claims relationship with Ugbawka. The people, however, hold tenaciously to the claim that they were friendly with Awkunanaw, Ugbawka, and Lengwe (Nenwe). Accordingly, it is considered a taboo for them to shed the blood of the people from these named towns (Milgov 1936).

At present, there is a plethora of legends regarding the people's origin. One of these myths is that of the movement of Amaegbele in Enuagu Amurri. It claims that the founding father of Amaegbele had first lived at the Obodo Okorochukwu axis. But overtime he left the area on a hunting expedition, and later settled at the present site of Amaegbele. Chief Rickey Nweke, an indigene of Enuagu Amurri ,appears to support this line of thinking with his claim that the palm and the ukwa(bread fruit) trees at Obodo Okorochukwu serve as a historical monument to prove that Amaegbele first settled near Afor Amurri (Nweke 2009).

\title{
4. Religious Relations: The Nnechukwu Phenomenon
}

In an article entitled, "The Niger Delta States and their Neighbours, to 1800", some years ago, E.J. Alagoa gave two reasons for the success of the Aro traders in Igboland. The first was the protective influence of the oracle, Ibini Ukpabi, at Arochukwu; the second reason had to do with the activities of the Abam, Edda, Ohafia, Abiriba and other mercenaries, who supported the Aro commercial operations. Beyond the Aro oracle, Alagoa reckoned with the influence of other oracles in Igbo hinterland. The closest rival to the Arochukwu oracle, he added, was probably the Agbala oracle at Awka (Alagoa 1976:361-2). Scholars on Igbo studies should, however, do well to reckon with the pervading influences of other oracles in Igboland before, during and after colonial rule. Worthy of mention here are the "Igwe-ka-Ala"; ("a king who is higher/greater than the land,") (Basden 1983:246) of Umunoha near Owerri and "Nnechukwu" (God's mother) of Amurri near Enugu. The latter of these two oracles is the subject of this section of the study.

Writing in 1936, Mr. Beaumont (the Assistant District Officer based at Agbani) described Nnechukwu as "Agbala juju". According to him, "for many years the town (Amurri) was famous for its AGBALA juju (Milgov 1936)." But his 
assertion was a misnomer as the town never had any relationship with the Agbala oracle said to be located at Ezi, Awka, and was believed to be the daughter of the Aro Long Juju (Basden1983). On the contrary, "Nnechukwu Ukpabi" is believed to trace its origin to Arochukwu. According to one informant during a field trip, it was not yet known the particular locality in Arochukwu from where this oracle originated and the time it got settled in Amurri (Nweke 2009). What is, however, important is that this oracle took on the name "Nnechukwu" to distinguish itself from the nature and operations of Ibini Ukpabi, the Arochukwu oracle (Nweke).

The Nnechukwu deity is situated at the Enuagu village of Amurri. It is from here that it operates. During the precolonial and colonial times, said a source, the influence of this oracle loomed large enough all over Nkanu land and beyond (Uwadiegwu 2009). People with diverse social, economic and political problems that required solutions normally consulted the oracle. Issues bordering on protection from the hands of the enemies, healing of diseases, difficulties in child-bearing and land arbitration were brought to the attention of the oracle from parts of the Nkanu clan for solutions. In time past, continued the source, Nnechukwu was reputed to be a true god to which people made petitions for good and vengeance (Atu 2009). Cases, the source maintained, which had defied arbitration by the elders in local communities, were referred to the deity for resolutions (Atu 2009) This probably was one way by which the deity became famous within and outside its locality.

Apart from arbitrating on thorny issues, Nnechukwu was particularly believed to have waded into issues bordering on child-bearing. This again was where the oracle distinguished itself as a 'miracle' worker. Couples with difficulties in child-bearing, an informant disclosed, normally consulted the oracle from parts of Nkanu and beyond. Before the oracle, the couple would make petitions and pledges (of their volition) regarding what to be done in appreciation of the god's magnanimity, should they be given a child (Nweke 2009). One of such pledges was the naming of the child after the oracle. Thus, when a child, whose parents had consulted the oracle was born, he/she would normally be dedicated, and named after it, according to the Igbo market day. If, for instance, the child was born on Afor market day, he would be named "Nwafo-Nnechukwu";if born on Eke day, he/she became, "Nweke-Nnechukwu," and so forth (Edemba 2009). In Ugbawka, cases of men and women with such names abound and such people are known to have been dedicated to the Nnechukwu oracle (Edemba 2009).

However, beginning from the immediate post-civil war years of 1970-1978, there appeared to have occurred some occasions of change and conflict in the oracle's role in the affairs of men and women. With the introduction of the new wave of Pentecostal radicalism in Nigeria, Amurri was "invaded" by a new wave of uncompromising Christian believers, whose activities, by extension, affected the influence of the oracle beginning from the 1970s. At the start of the movement between 1970 and 1973, the new men and women, variously described as the "born-agains", "Ndi-uka-akwa" (people of the crying Church, apparently because of their mode of preaching and praying) and/or S.U. (the Scripture Union Group), were rejected by the orthodox Churches and the Nkanu communities (Ani 2009). Nevertheless, with the zeal, resilience and persistence on the part of the members of these groups drawn from different towns in Nkanu, the Nkanu Christian Union (N.C.U) was born in 1976, with the aim of evangelising Nkanuland (Nwafor 2009). Earlier in 1974, the Ugbawka Christian Union (UCU) was established, with the intent of evangelising Ugbawka town. The activities of these nondenominational groups and the emergence of the new Pentecostal churches in parts of Nkanu land and Amurri, in particular, had their impact on the Nkanu clan. These Christian groups, said one witness, no doubt, led to a relative decline in the influence of the Nnechukwu oracle in the social circles In the political circles. It is, however, a known fact that prominent Nigerian politicians still patronise the oracle for protection and fortune-telling (Agwu 2009).

\section{Judicial Relations}

In an assessment of the state of development in parts of emerging Nigeria in 1900, Frederick D. Lugard said of the Southern Provinces, particularly the Igbo areas that

By the time when Native courts were established in Eastern part of the Southern Provinces, the tribal system and authority had broken down and had been succeeded by anarchy under the disintegrating influences of successful middlemen traders and the Aros. The latter were professional slave traders, and ruled by the terror of their juju...(see Onwuejeogwu 2007:56)

As a way out, he prescribed that native courts be established and warrant chiefs be appointed. Thus, by 1914 warrant chiefs were appointed in some parts of Igboland. This system, however, was to collapse in 1927 (Onwuejeogwu 2007).

The above assertion by Lugard referring to an alleged breakdown of law and order may be an unfair assessment of 
the Igbo nation where there had been institutions of traditional administration and cohesion as exemplified in the village government and local dispute arbitration processes before the inauguration of British colonial rule in Nigeria (Chukwu 2002: chapter One). What the British did in this part of the country was to villify the existing social structures to justify the introduction of a semblance system to be manned by their own appointed agents and officials like the warrant chiefs, court clerks, messengers and councillors. This line of thinking becomes justifiable in view of the fact that the issue adjudicated upon in the British-established native courts were not any different from what had obtained in the earlier court system (Milgov 1936:17).

In this section of the study, we consider how Ugbawka and Amurri, under the British- supervised system, federated for judicial purposes. Three factors might have recommended the federation of the two towns in respect of a group court. They were:

1. Similarity of their customs and organisation;

2. Proximity as the two towns adjoin each other; and

3. Availability of sufficient funds to run the group court (Milgov 1936).

But we may also add as a factor that recommended the federation, the issue of insufficient British personnel to man separate courts for each of the two towns. It is a known fact that throughout the colonial period in Nigeria, the British resorted to the group courts system due to the dearth of English personnel. For instance, following the promulgation of the Native Court Ordinance of 1914 and the Native Authority Ordinance of 1916, Chief Onyema Onwusi of Eke was appointed the Native Authority of the Agbaja clan comprising the Eke, Udi and Oji River Native Court Areas (Annual Report 1921).

In the early years of colonial rule in Igboland, the whole of Nkanu area was under the Udi Division and by extension under the jurisdiction of the Udi Native court. However, following the proclamation of the Provincial Court Ordinance of 1916, a Native court was opened at Agbani. Meanwhile, as a result of the proclamation of the Native Authority Ordinance of 1916, the Nkanu Native Authority was created with Agbani as the headquarters and at the same time it retained the seat of the Native Administration Treasury (Mbah 1997:81). With these developments, Ugbawka and Amurri were made to attend the Agbani court sessions.

Following the establishment of the Nara sub-court in the later years Ugbawka elected to attend the newly opened court at Nara. The decision was probably taken due to the fact that Nara was more conveniently situated. On its part, Amurri continued to attend the Agbani court. For the Nara sub-court, Ugbawka had three court members at the beginning-although the number was increased to four in 1923 (Milgov 1936). Between 1923 and 1925, Amurri pulled out of the Agbani court due to the alleged oppressive tendencies of the president of the court, Chief Chukwuani Nwangwu of Ozalla (NAE/UDDN. Re-organisation of Native Authority 1951-53;NAE/CSE Native Court 1934). As a follow-up, Amurri elected to transfer its membership to the Owelli court in Awgu District. But this arrangement could not be sustained owing to logistic difficulties associated with supervision, and the result was the re-transference of the town to the Udi District (Ibid).

By mid-1933 or so, there were mounting pressures pointing to the need for a re-organisation of the Nkanu Native Authority and a possible strengthening of the Native courts to make them more effective (Ibid). It has been pointed out that the demand for a possible re-organisation of the Authority followed a sudden upsurge in criminal activities in different parts of Nkanu land, which the existing number of Native Courts was incapable of addressing. Also, there was a general dissatisfaction with the punishment meted out by the existing courts in respect of certain categories of offences like theft of livestock and farm produce (Milgov 1956). Besides, the process of prosecuting criminal offenders in native courts was less than satisfactory; hence it was proposed that fees for commencement of criminal proceedings be reduced considerably (Milgov 1936). Following the report on the existing structure and the proposal for an improvement by Beaumont, the ADO at Agbani, seven more native courts were established in Nkanu in 1934. The courts were located at Akpugo, Amagunze, Akegbe-Ugwu, Idodo, Mburubu, Nike and Ugbawka. The Ugbawka court, located at Ibe Agu, an outskirt of Amauzam Ugbawka, overlooking the rail line, was meant to serve Ugbawka and Amurri village groups (Milgov 1936).

The Ugbawka court was Group 'D' with limited powers over civil actions in which debt demand or damages did not exceed $£ 10$, as well as full jurisdiction on all matrimonial cases other than those that arose from or connected with a Christian marriage. Besides, the court had jurisdiction in matters that had to do with land and criminal cases which could be punished by imprisonment for the equivalent according to native law and custom (Milgov 1936).

Membership of the group court portrayed visible elements in inter-group relations between the two towns. Representation on the court was somewhat based on kindred/ family or territorial unit (in the case of slave-born representatives in each of the two towns (Milgov 1936).According to the principle of kindred representation, each kindred was to select and forward the names of its representatives to the ADO at Agbani for ratification. Accordingly, Ugbawka 
had 56 court members, while Amurri had 31, based on kindred families in each town (Milgov 1936).

Considering the precision with which the court representatives at the Ugbawka court discharged their duties, the $A D O$ in charge of the Nkanu area was said to have described the court in 1936 as "probably the best of the several councils". He added that the members combined common sense with dignity and that their authority was acceptable to the people (Milgov 1936). Note should, however, be taken that following the free-born/ slave-born rift in Ugbawka in 1923, the latter group had agitated for separate representation at the Agbani court. However, to assuage the feelings of an alleged marginalization by the slave born in Ugbawka, a court member was appointed at Isigwe Ugbawka to represent the slave-born (Milgov 1936). In Amurri town, no representative was appointed as a member of the court for the slaves since they were small in number and did not demand for any separate representation. In fact, it is said that both at the Agbani court and the Nara sub-court from 1923, one slave-born court member sat monthly with three free-born court members (Milgov 1936).

The Amurri-Ugbawka Group Native Court was said to have outlived the colonial period. Its activities appear to have been halted by the Nigerian Civil War (1967-1970). At the end of the war in 1970, many political developments in Nigeria and the East Central State did a lot to alter the political equation in Nkanuland, not the least Ugbawka and Amurri. (We intend to examine this briefly in the next section of the study). Meanwhile, what seems obvious is that the establishment of a group court at Ibe Agu, Amauzam Ugbawka would have undeniably contributed in cementing an already existing cordial relationship between Ugbawka and Amurri. But the siting of the court at Ugbawka might have had its negative effect on Amurri as a community. As one informant from Amurri would argue in an interview:

The group court cemented our relationship with Ugbawka, no doubt. But, for as long as the court lasted it was widely cited as Ugbawka Court because of its siting there. I tell you the siting of the court at Ugbawka almost swallowed up the named Amurri or as it used to be, Amurri-Ugbawka. Thank God today we have our identity as a separate group.(Nweke 2009)

But the informant tended to have forgotten that whichever way, the court would still have been sited somewherewhether it was in Ugbawka or Amurri- to serve the desired purpose. For instance, when it was known as the Nkanu Native Authority with Agbani as the headquarters other towns in Nkanu, including Ugbawka and Amurri, attended the court sessions. Ugbawka as we pointed out elsewhere in the paper was once a member of the Nara sub-court.

\section{Later-Day Developments and the Ugbawka- Amurri Relations}

At this point, it may be necessary to highlight, for records, some of the post-civil war developments in Nigeria that led to the "severance" of relations between Ugbawka and Amurri. These developments were more of political nature. At present, the two towns belong to different Local Government Areas in Enugu State of Nigeria.

The post-civil war developments trace their roots to the transition-to-civil-rule programme of the mid-1970s. Among other things, they had sought to divide (and indeed divided) each Nigerian political state into five senatorial zones. In the former Anambra State, the old Nkanu Local Government Area, among other local council areas, was made to belong to the Enugu Senatorial Zone. Also, as a federal constituency, the Nkanu council area was further divided into four constituencies: Nkanu West, Nkanu Central, Nkanu South and Nkanu North. The West constituency consisted among other towns, Akegbe-Ugwu, Obuofia and Amurri (one of our study areas). On its part, the Nkanu South constituency comprised among others Nomeh, Nara, Nkerefi and Ugbawka (part of the study area) (Nweke 2009).

From the foregoing account, it may be possible for the reader to understand how Amurri and Ugbawka, "severed" their relations. While the former belonged to the old Nkanu West Constituency, Ugbawka was made a member of the old Nkanu South Constituency. As at the time of writing up this paper, the two towns belong to separate Local Government Areas. While Ugbawka belongs to Nkanu East Local Government Area, Amurri is in Nkanu West Local Government Area.

Commenting on the severance of the relationship between Ugbawka and Amurri, and the grouping of the latter to the Nkanu West Constituency in 1977, Chief Ricky Nweke of Amurri quoted Chief David Ngene (from Obuofia Awkunanaw) who was the Chairman of the old Nkanu Local Government Council between January 1977 and July 1979, as saying that in causing Amurri to belong to Nkanu West Constituency in 1979, he and other Awkunanaw leaders were not oblivious of the existing blood relationship between Amurri and the Awkunanaw group of clans (Nweke 2009). By extension, the new constituency delineation avoided the use of court area as a principle, which, if had been applied, would have resulted in Ugbawka and Amurri belonging the same state constituency and same local government council area. 


\section{Conclusion}

By now, the reader would have been convinced or otherwise, as to the choice of the topic. The subject of inter-group relations, especially in the developing African society, is sometimes difficult to define. This is because commentators of the Western school often cast group relations in Africa in the mould of wars, crises and murders. To them, therefore, group relations refer to destruction. However, in our examination so far, we have been able to establish how groups, without any traces of biological ties, were able to conduct century-long economic, social and judicial relations. For instance, the request by the leaders of Amurri and Ugbawka for a judicial federation during the colonial period could have only been informed by a natural desire to further strengthen the existing social and economic bonds existing between the two close-door neighbours. Throughout the field trips for this paper, the researcher was spared of the stories of intercommunity wars over land disputes between both towns. This, according to investigations, was probably because of a manifest show of restraint and wisdom by the people. Perhaps, the case of Ugbawka and Amurri may have contrasted sharply with what the situation was between Ugbawka on the one hand, and Agbani, Akpugo, Ihuokpara, Nara and Nomeh, on the other hand, where issues of land dispute occasionally resulted in the loss of lives and property.

At present, Ugbawka and Amurri belong to different political blocs. But this is not peculiar to the two towns. This political gerrymandering also applies to other Nkanu groups. In the Nigerian federation, the Igbo, Yoruba and HausaFulani groups have been split into different states for purposes of social, economic and political development. This arrangement, notwithstanding ,a call for a group meeting is known to have always brought these ethnic nationalities, especially the Yoruba and Hausa-Fulani groups, to a solidarity point. Can the same be said of Amurri and Ugbawka, nay, Nkanu groups, irrespective of their political divides?

\section{References}

Afigbo, A.E. (1981) Ropes of Sand: Studies in Igbo History and Culture. Nsukka: University of Nigeria Press.

Afor-Ebe, N. (1999). Product of an oral interview at Amauzam Ugbawka.

Agwu, K.C. (2009). Product of an oral interview at Agbani.

Alagoa, E.J. (1976). "The Niger Delta States and their Neighbours, to 1800" in J.F.A. Ajayi and Michael Crowder (eds) History of West Africa $2^{\text {nd }}$ ed. (London: Longman), pp. 361-2.

Ani, P.O. (2009). Product of an oral interview at Isigwe Ugbawka.

Animba, D.N. (2009). Product of an oral interview at Amauzam Ugbawka.

Anyanwu, E. (2007). Product of an oral interview at Umuisu Ugbawka.

Atu, O. (2009). Product of an oral interview at Amurri.

Basdan, G.T. (1983). Among the Ibos of Nigeria (Onitsha: University Publishing Company).

Chukwu, D. O. (2002). An Introduction to Nigerian Political History $2^{\text {nd }}$ ed. Enugu Rhema Publications, Chapter One.

Chukwu, D. O. (2008). "The Challenges of the Biafran War Technology", in Armstrong Matiu Adejo (ed), The Nigerian Civil War: Forty Years After, What Lessons? Makurdi: Aboki Publishers.

Chukwu, D. O. (2010). "Trends and Changes in the Nigerian Currency System, Colonial Period - 2008," Studies of Tribes and Tribal vol. 8 No.2, pp.87 -101.

Chukwu, D. O. and Madubuko, C.C. (2014). "Racism, Hamitic Hypothesis and African theories of Origin: the unending Debate." Journal of Integrative Humanism, vol. iv No.3, pp.85-96.

Davis, A.J. (1968). "Hamitic Hypothesis in Retreat?" Journal of the Historical Society of Nigeria vol. iv No. 3, p. 483.

Edeh, Godwin (1999). Product of an oral interview at Amauzam Ugbawka.

Edemba, N. O. (2009). Product of an oral interview at Amauzam Ugbawka.

Enechukwu, A. (1993). History of Nkanu Enugu: Kaunof Publishers.

Ezeh, D., Mbah, S. and Ezeah, O. (1999). The Wawa Struggle Enugu: Delta Publications Ltd.

Hair, E.E. "Unpublished Study of Enugu." Not dated.

Hegel, G.W.F. (2001). The Philosophy of History. Ontario: Batoche Books.

Kirk-Greene, A.H.M. (1960). "Major Currencies in Nigerian History, "Journal of the Historical Society of Nigeria, vol. 2 No. 1.

Mbah, S.I. (1997). A History of Ugbawka: From Pre-colonial Times to the Present. Enugu: Reynolds Publishers.

Newton, A.P. (1922-3). "Africa and Historical Research" Journal of African Society vol. 22, p 267.

Nigeria: Constitution of Amauzam Ugbawka (2006).

Nigeria: NAE/ONPROF 7/12/99 OP 404/1925 Annual Assessment Reports on Chiefs for the year 1921, Onitsha Province.

Nigeria: NAE/MILGOV. 13/1/15, Intelligence Report on Amurri - Ugbaka Village Groups, Nkanu, Udi Division 1936.

Nigeria: NAE/UDDIV 4/1/42, Re-organisation of Native Authority, 1951-1953

Nigeria: NAE/CSE 21/10/1, Native Court, Warrant Establishing Amurri -Ugbawka Group Native Court Onitsha Province 1934.

Nigeria: NAE/ENLA 1/7/4 File 4, Enugu Township Report.

Horton, W.R.G.(1954). "The Ohu System of Slavery in a Northern Ibo Village Group," AFRIKA 24, p.317.

Nwafor, P. (2009). Product of an oral interview at Obeagu, Awkunanaw. 
Nweke, R. (2009). Product of an oral interview at Amurri.

Obi-Ani, P. (1999). "Abolition and Slave-freeborn Relationship in Nkanu,"Nsukka Journal of the Humanities NO.10, pp. 186 - 198.

Okoye, T.O. (1996). The City in South-eastern Nigeria. Onitsha: University Publishing Company.

Onwuejeogwu, M.A. (2007). Osili Factor in the Culture History of Enugwu Ukwu. Agbor: Sky Press.

Seligman, C.R. (1957). Races of Africa. London: Oxford University Press.

Trevor - Roper, H. (1963). The Listener or www.daviderick.werdpress/com/2010/06/09 there-is-no-African history.

Ukwu, U.I. (1996). "Markets in Igboland" in B.W. Hodder and Ukwu I. Ukwu (eds) Markets in West Africa. Ibadan: University Press. Uwadiegwu, S.(2009). Product of an oral interview at Amurri.

Uya, E.O. (2004). African History: Some Problems in Methodolgy and Perspective, $2^{\text {nd }}$ ed, Calabar: CATS Publishers. 